\title{
Retrospective study of pulmonary and extrapulmonary tuberculosis cases in Giza Governorate during the period of 2014- 2018
}

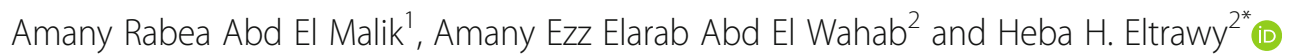

\begin{abstract}
Background: Tuberculosis in Egypt is a main public health problem. Egypt is categorized among the mid-level incidence countries. The objective of this work is to study the epidemiology of TB in Giza Governorate during the period from 2014 to 2018.

Results: This study revealed that the total number of TB cases in Giza Governorate during the period from 2014 to 2018 was 3357 (2035 males and 1322 females including 199 children) with the highest number of cases in 2017 ( $n=$ 770 cases). The highest incidence occurred in the age group $18-65$ years (86.3\%\%, 78.8\%, 83.8\%, 84.2\%, and 87.1\%) and male gender $(56.8 \%, 62.8 \%, 59.9 \%, 61.3 \%$, and $61.5 \%)$ during the study period, respectively, and in urban residence, the higher percentage occurred in PTB than EPTB in 2014, 2015, 2016, and 2018 (66.2\%, 58.9\%, 57.3\%, and 55.5\%), respectively, while the incidence of the extra PTB was higher than PTB in 2017 (51.6\% versus 48.4\%). The increased incidence of new cases $(92.9 \%, 89.6 \%, 92.7 \%, 91.8 \%$, and 92.9\%) during the 5 studied years are smearpositive and cure outcome $(86.3 \%, 87.7 \%, 88.7 \%, 83.4 \%$, and $83.4 \%$, respectively)

Conclusion: Young, middle-aged male, and new smear-positive cases were highest in percentage. The highest percentage of PTB (66.2\%) was registered in 2014, and the highest percentage of EPTB (51.6\%) was registered in 2017. The increased percentage of cure outcome was during the period from 2014 to 2018 in Giza Governorate.
\end{abstract}

Keywords: Tuberculosis, Pulmonary, Extrapulmonary tuberculosis

\section{Background}

Tuberculosis (TB) is an infectious disease caused by the bacillus Mycobacterium tuberculosis. The disease typically affects the lungs (pulmonary TB) but can affect other parts of the body as well as extrapulmonary TB [1].

$\mathrm{TB}$ represents the second leading cause of death from an infectious disease worldwide after HIV infection [2].

The prevalence rate of TB in Egypt was 26 per 100,000 people according to the World Health Organization estimate in 2014, while the incidence rate was 15 per 100 ,

\footnotetext{
* Correspondence: hebahamed182@gmail.com

${ }^{2}$ Chest Department, Faculty of Medicine for Girls, Al-Zahraa University

Hospital, 11517 Al-Abbaseya, Cairo, Egypt

Full list of author information is available at the end of the article
}

000 people. Screening, diagnosis, notification, and registration of TB cases were implemented all over Egypt according to the National TB Strategy of the National Tuberculosis Control Program (NTB) [3].

Egypt has massively engaged in early case detection, provision of adequate chemotherapy, and prevention of transmission to new cases [3].

So the objective of this work was to study the epidemiology of TB in Giza Governorate during the period from 2014 to 2018.

\section{Methods}

This was a retrospective study involving a record review of notified, registered, and treated TB patients in the 
chest hospital and clinics in Giza Governorate during the period from 2014 to 2018.

It includes Imbaba, Om El Almasreen, Oseem, El Ayat, Elbadrasheen, El Saff, and Atfeeh. All data were collected from the chest hospitals (two hospitals) and chest dispensaries (5 dispensaries) in El-Giza Governorate.

We analyzed TB cases reported from January 2014 to December 2018. The diagnosis of TB in Giza Governorate is made in line with the National Egyptian TB Control Program Guidelines of the Ministry of Health

\section{Collection and analysis of data}

- Sociodemographic data.

- Patient classification group: new, relapse, treatment after failure, default or cured.

- Forms of tuberculosis; either pulmonary (smearpositive or smear-negative) or extrapulmonary (and its site as LN, intestine, meninges, breast, renal).

- Method of diagnosis: bacteriological, e.g., smear analysis, gene Xpert or culture, radiological, pathological, and radio pathological.

- Schedule of treatment (recommended treatment regimen according to NTP).

- The recorded follow-up for smear-positive pulmonary tuberculosis.

- Outcome: cure, treatment completion, treatment failure, death, or default.

\section{Ethics approval}

The ethics approval to use, report, and publish the collected data was obtained from the Ministry of Health, Egypt. Patient information was anonymized and deidentified prior to the analysis. Also, this study was approved by the Institutional Review Board of the Faculty of Medicine for Girls (the committee's reference number IRB 201910179), Al-Azhar University/Cairo branch on October 1, 2019, and was obliged to the standards of the Declaration of Helsinki.

\section{Statistical analysis}

Data were collected into a paper form by authors. Data were fed to the computer as an Excel sheet (Microsoft
Corporation, Redmond, WA, USA) and were validated and analyzed by SPSS program version 15 (SPSS Inc., Chicago, IL, USA). A descriptive analysis was done. Comparisons were done among variables using the chisquared test. A chi-squared test was used to evaluate the differences in proportions. Comparisons at $p<.05$ were considered significant.

\section{Results}

Table 1 showed that during the 5 years of study, the highest incidence occurred in the age group 18-65 years (86.3\%\%, $78.8 \%, 83.8 \%, 84.2 \%$, and $87.1 \%$, respectively) and the lowest incidence occurred at the extremes of age, the age group less than 1 year $(0.4 \%, 1.3 \%, 0.9 \%$, and $0.3 \%$ ) except in $2015(6.4 \%)$ and more 65 years $(2.4 \%, 3.8 \%, 3.6 \%, 4.0 \%$, and $4.6 \%)$ with a highly statistically significant difference $p$ value $<0.001$ between studied years as regards age categories.

Table 2 showed that no statistical significant difference ( $p$ value $>0.05$ ) between studied years as regards sex and residence of studied patients with higher incidence occurred in both male gender $(56.8 \%, 62.8 \%, 59.9 \%$, $61.3 \%$, and $61.5 \%)$ and urban residence $(88.0 \%, 91.9 \%$, $90.8 \%, 92.1 \%$, and $92.0 \%)$. While there was highly statistical significant difference $(p$ value $<0.001)$ between the studied years as regards TB form in the studied patients with higher percentage in PTB than in extra PTB in 2014, 2015, 2016, and 2018 (66.2\%, 58.9\%, 57.3\%, and $55.5 \%$, respectively) while the incidence of extra PTB was higher than of PTB in 2017 (51.6\% versus 48.4\%).

Table 3 demonstrated that there was a statistically significant difference $(p$ value $<0.05)$ between the 5 studied years as regards patient classification group with the highest incidence of new cases $(92.9 \%, 89.6 \%, 92.7 \%$, $91.8 \%$, and $92.9 \%$, respectively) during the 5 studied years followed by the relapse and failure and the lowest incidence of resistant cases $(0.6 \%, 1.4 \%, 0.4 \%, 0.5 \%$, and $0.1 \%$, respectively).

Table 4 demonstrated that there was highly statistical significant difference ( $p$ value $<0.001)$ between the studied years as regards the method of diagnosis in studied patients with the highest percentage of bacteriological (smear positive) $(59.2 \%, 47.6 \%, 48.6 \%, 46.0 \%$, and 50.6\%)

Table 1 Distribution of cases according to age group during the period of the study

\begin{tabular}{|c|c|c|c|c|c|c|c|c|c|c|c|c|}
\hline Year/age & $\begin{array}{l}2014 \\
(N=\end{array}$ & & $\begin{array}{l}2015 \\
(N=\end{array}$ & & $\begin{array}{l}2016 \\
(N=\end{array}$ & & $\begin{array}{l}2017 \\
(N=\end{array}$ & & $\begin{array}{l}2018 \\
(N=\end{array}$ & & $\begin{array}{l}X^{2} \\
p \text { value }\end{array}$ & \\
\hline < 1 year & 2 & $0.4 \%$ & 40 & $6.4 \%$ & 9 & $1.3 \%$ & 7 & $0.9 \%$ & 2 & $0.3 \%$ & 114.4 & HS \\
\hline 1-11 years & 19 & $3.6 \%$ & 39 & $6.2 \%$ & 42 & $5.9 \%$ & 40 & $5.2 \%$ & 27 & $3.8 \%$ & & \\
\hline $12-17$ years & 39 & $7.3 \%$ & 30 & $4.8 \%$ & 39 & $5.5 \%$ & 44 & $5.7 \%$ & 30 & $4.2 \%$ & & \\
\hline $18-65$ years & 459 & $86.3 \%$ & 493 & $78.8 \%$ & 598 & $83.8 \%$ & 648 & $84.2 \%$ & 623 & $87.1 \%$ & & \\
\hline$>65$ years & 13 & $2.4 \%$ & 24 & $3.8 \%$ & 26 & $3.6 \%$ & 31 & $4.0 \%$ & 33 & $4.6 \%$ & & \\
\hline
\end{tabular}

$X^{2}$ Chi-squared test

$H S p$ value $<0.001$ is considered highly significant 
Table 2 Distribution of cases according to sex, residence, and TB form during the study period

\begin{tabular}{|c|c|c|c|c|c|c|c|c|c|c|c|c|}
\hline Year/sex & \multicolumn{2}{|c|}{$\begin{array}{l}2014 \\
(N=532)\end{array}$} & $\begin{array}{l}2015 \\
(N=626)\end{array}$ & \multicolumn{3}{|c|}{$\begin{array}{l}2016 \\
(N=714)\end{array}$} & \multicolumn{2}{|c|}{$\begin{array}{l}2017 \\
(N=770)\end{array}$} & \multicolumn{2}{|c|}{$\begin{array}{l}2018 \\
(N=715)\end{array}$} & $\begin{array}{l}x^{2} \\
p \text { value }\end{array}$ & \multirow{3}{*}{ NS } \\
\hline Male & 302 & $56.8 \%$ & 393 & $62.8 \%$ & 428 & $59.9 \%$ & 472 & $61.3 \%$ & 440 & $61.5 \%$ & \multirow{2}{*}{$\begin{array}{l}5.06 \\
0.280\end{array}$} & \\
\hline Female & 230 & $43.2 \%$ & 233 & $37.2 \%$ & 286 & $40.1 \%$ & 298 & $38.7 \%$ & 275 & $38.5 \%$ & & \\
\hline Year/residence & \multicolumn{2}{|c|}{$\begin{array}{l}2014 \\
(N=532)\end{array}$} & \multicolumn{2}{|l|}{$\begin{array}{l}2015 \\
(N=626)\end{array}$} & \multicolumn{2}{|c|}{$\begin{array}{l}2016 \\
(N=714)\end{array}$} & \multicolumn{2}{|c|}{$\begin{array}{l}2017 \\
(N=770)\end{array}$} & \multicolumn{2}{|c|}{$\begin{array}{l}2018 \\
(N=715)\end{array}$} & $\begin{array}{l}x^{2} \\
p \text { value }\end{array}$ & \\
\hline Rural & 64 & $12.0 \%$ & 51 & $8.1 \%$ & 66 & $9.2 \%$ & 61 & $7.9 \%$ & 57 & $8.0 \%$ & 8.6 & \multirow[t]{3}{*}{ NS } \\
\hline Urban & 468 & $88.0 \%$ & 575 & $91.9 \%$ & 648 & $90.8 \%$ & 709 & $92.1 \%$ & 658 & $92.0 \%$ & 0.071 & \\
\hline Year/form & \multicolumn{2}{|c|}{$\begin{array}{l}2014 \\
(N=532)\end{array}$} & \multicolumn{2}{|l|}{$\begin{array}{l}2015 \\
(N=626)\end{array}$} & \multicolumn{2}{|c|}{$\begin{array}{l}2016 \\
(N=714)\end{array}$} & \multicolumn{2}{|c|}{$\begin{array}{l}2017 \\
(N=770)\end{array}$} & \multicolumn{2}{|c|}{$\begin{array}{l}2018 \\
(N=715)\end{array}$} & $\begin{array}{l}x^{2} \\
p \text {-value }\end{array}$ & \\
\hline Pulmonary & 352 & $66.2 \%$ & 369 & $58.9 \%$ & 409 & $57.3 \%$ & 373 & $48.4 \%$ & 397 & $55.5 \%$ & 42.5 & \multirow[t]{2}{*}{ HS } \\
\hline Extra-pulmonary & 180 & $33.8 \%$ & 257 & $41.1 \%$ & 305 & $42.7 \%$ & 397 & $51.6 \%$ & 318 & $44.5 \%$ & $<0.001$ & \\
\hline
\end{tabular}

$X^{2}$ Chi-squared test

NS: $p$ value $>0.05$ is considered non-significant

followed by the pathological and radiological and lowest percentage was bacteriological (smear negative) $(0.6 \%$, $0.6 \%, 1.0 \%, 0.1 \%$, and $0.1 \%$, respectively).

Figure 1 showed that there was a highly statistically significant difference ( $p$ value $<0.001)$ between the studied years as regards treatment outcome in studied patients with the highest percentage of cured cases outcome $(86.3 \%, 87.7 \%, 88.7 \%, 83.4 \%$, and $83.4 \%$, respectively).

\section{Discussion}

TB in Egypt is considered an important community health problem. Delay in the detection of pulmonary and laryngeal cases increases the chances of transmission [4].

There has been a major decline in the TB death rate in the last two decades, but the progress needs to be faster to fulfill the post-2015 WHO TB strategy to end the TB epidemic by 2035; with the global targets of a $95 \%$ decrease in the number of TB mortalities and a $90 \%$ reduction in TB cases [5].

Thus, the aim of this work was to study the epidemiology of TB in chest hospitals and clinics in Giza Governorate during the period from 2014 to 2018.

Our study revealed that the total number of TB cases was 3357 (2035 males and 1322 females including 199 children) with the highest number of cases in 2016,
2017, and 2018 with a peak in 2017 ( $n=770$ cases). The higher incidence of TB occurred in males than in females in the five studied years (Table 2) which was in concordance with most individual governorate studies $[3,6-10]$. This variance may be due to less awareness in females as many female patients do not ask for medical advice because of factors such as illiteracy and the traditions predominant in the society, which may prohibit them from going out and seeking medical advice. TB stigma is felt more strongly in females [11]. Moreover, the awareness in men is higher, indicating the differences in exposure to more outdoor activities and contact. Transfer from infection to disease owing to sex differences was related to other risk factors for TB such as cigarette and shisha smoking [12].

These findings were in disagreement with that of Mohamed et al. [1] who studied TB in patients admitted to the Assiut Chest Hospital from 2005 to 2009, where it was $70.87 \%$ for females and $29.13 \%$ for males. They attributed the higher prevalence of TB in women to men in their study due to different conditions in Upper Egypt, where females especially farmers have a chief role of work outside or inside the home, with a greater chance of exposure to infection.

This study reported that the higher incidence of TB occurred in the age group 18-65 years may be due to a high prevalence of smoking behavior in this active age

Table 3 Distribution of cases according to patient registration type during the study period

\begin{tabular}{|c|c|c|c|c|c|c|c|c|c|c|c|c|}
\hline \multirow{2}{*}{$\begin{array}{l}\text { Year/patient registration type } \\
\text { New }\end{array}$} & \multicolumn{2}{|c|}{$\begin{array}{l}2014 \\
(N=532)\end{array}$} & \multicolumn{2}{|c|}{$\begin{array}{l}2015 \\
(N=626)\end{array}$} & \multicolumn{2}{|c|}{$\begin{array}{l}2016 \\
(N=714)\end{array}$} & \multicolumn{2}{|c|}{$\begin{array}{l}2017 \\
(N=770)\end{array}$} & \multicolumn{2}{|c|}{$\begin{array}{l}2018 \\
(N=715)\end{array}$} & \multicolumn{2}{|c|}{$\begin{array}{l}X^{2} \\
p \text { value }\end{array}$} \\
\hline & 494 & $92.9 \%$ & 561 & $89.6 \%$ & 662 & $92.7 \%$ & 707 & $91.8 \%$ & 664 & $92.9 \%$ & 25.4 & $S$ \\
\hline Resistant & 3 & $0.6 \%$ & 9 & $1.4 \%$ & 3 & $0.4 \%$ & 4 & $0.5 \%$ & 1 & $0.1 \%$ & 0.013 & \\
\hline Relapse & 28 & $5.3 \%$ & 35 & $5.6 \%$ & 25 & $3.5 \%$ & 35 & $4.5 \%$ & 22 & $3.1 \%$ & & \\
\hline Failure & 7 & $1.3 \%$ & 21 & $3.4 \%$ & 24 & $3.4 \%$ & 24 & $3.1 \%$ & 28 & $3.9 \%$ & & \\
\hline
\end{tabular}

$X^{2}$ Chi-squared test

$\mathrm{S}: p$ value $<0.05$ is considered significant 
Table 4 Distribution of cases according to the method of diagnosis during the study period

\begin{tabular}{|c|c|c|c|c|c|c|c|c|c|c|c|}
\hline \multirow{2}{*}{$\begin{array}{l}\text { Year/method of diagnosis } \\
\text { Radiological }\end{array}$} & \multicolumn{2}{|c|}{$\begin{array}{l}2014 \\
(N=532)\end{array}$} & \multicolumn{2}{|c|}{$\begin{array}{l}2015 \\
(N=626)\end{array}$} & \multicolumn{2}{|c|}{$\begin{array}{l}2016 \\
(N=714)\end{array}$} & \multicolumn{2}{|c|}{$\begin{array}{l}2017 \\
(N=770)\end{array}$} & \multicolumn{2}{|c|}{$\begin{array}{l}2018 \\
(N=715)\end{array}$} & \multirow{2}{*}{$\begin{array}{l}X^{2} \\
p \text { value } \\
101.4\end{array}$} \\
\hline & 29 & $5.5 \%$ & 47 & $7.5 \%$ & 41 & $5.7 \%$ & 18 & $2.3 \%$ & 24 & $3.4 \%$ & \\
\hline Pathological & 113 & $21.2 \%$ & 152 & $24.3 \%$ & 179 & $25.1 \%$ & 194 & $25.2 \%$ & 122 & $17.1 \%$ & \\
\hline Bacteriological (smear negative) & 3 & $0.6 \%$ & 4 & $0.6 \%$ & 7 & $1.0 \%$ & 1 & $0.1 \%$ & 1 & $0.1 \%$ & \\
\hline Bacteriological (smear-positive) & 315 & $59.2 \%$ & 298 & $47.6 \%$ & 347 & $48.6 \%$ & 354 & $46.0 \%$ & 362 & $50.6 \%$ & $<0.001$ \\
\hline Radio-pathological & 72 & $13.5 \%$ & 125 & $20.0 \%$ & 140 & $19.6 \%$ & 202 & $26.2 \%$ & 206 & $28.8 \%$ & \\
\hline
\end{tabular}

group and more exposure to infection [10], and the lowest incidence occurred at the extremes of age, the age group less than 1 year $(0.4 \%, 1.3 \%, 0.9 \%, 0.3 \%)$ except in $2015(6.4 \%)$ and more 65 years $(2.4 \%, 3.8 \%, 3.6 \%, 4.0 \%$, $4.6 \%$ ) (Table 2) which agreed with Mori and Leung [13] who stated that in Africa, the age group of 15-44 years comprised about $74 \%$ of the population, whereas in the USA, this age group was only $24 \%$; therefore, in highprevalence settings, TB affects the most productive age groups which necessitates more attention in TB control programs targeting those age groups.

This study showed that the higher incidence of TB during the 5 years study occurred in urban than rural areas (Table 2) which can be explained by the possibility of overcrowding in the urban areas, especially the slums with lack of proper aeration and increase of air pollution.

There is a difference in the distribution of TB between governorate studies where El-Behira [6], Dakahlia [14],
Qalyobia, Minofia, Assiut [1], Sohag [15], and Aswan [3] showed that TB cases were more in rural areas. Those studies explained that higher TB cases in rural areas owing to poverty, drinking contaminated milk, exposure to cough spray from infected cattle, or close physical contact with infected animals. But our results were in agreement with studies in Sharkia [16] and Ismailia [13] as TB cases were higher in those studies in the urban areas.

This study reported that the higher percentage in PTB than extra PTB in 2014, 2015, 2016, and 2018. The highest percentage of PTB was in 2014 (66.2\%), while the highest percentage of EPTB was in 2017 (51.6\%), Table 2. Similarly, Essawy et al. (2016) [17] found that $72.8 \%$ were PTB and $27.2 \%$ were EPTB with a significant difference in the years 2009, 2007, and 2006.

This study reported that the higher percentage was in new cases than other patient classification groups with a

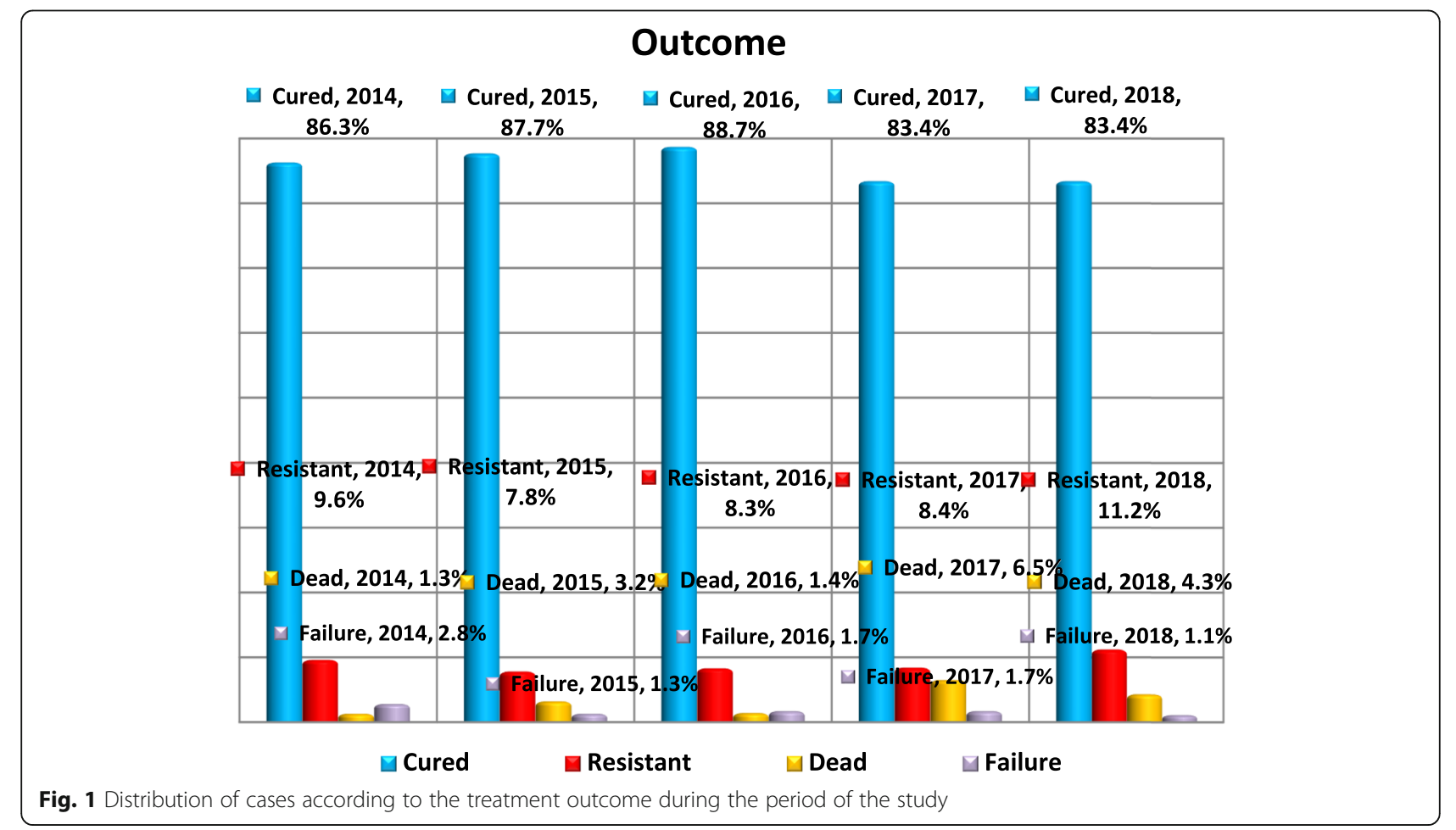


peak in 2018 (92.9\%); however, the lowest percentage is in resistant cases which can be explained by increasing awareness of cases by treatment protocol (Table 3). Also, this study reported that smear-positive diagnosed cases were the highest used method of diagnosis during the studied 5 years than other methods (Table 4) which are in concordance with Allam et al. 2019 [18] who found that Upper Egypt has higher incidence rates of new adult smear-positive cases and new extrapulmonary TB cases.

As regards the outcome in studied patients, our study revealed the highest percentage of cured cases outcome (86.3\%, 87.7\%, 88.7\%, 83.4\%, and 83.4\%, respectively) in Giza Governorate during the period from 2014 to 2018 (Fig. 1).

\section{Conclusions}

The TB affects the most productive age groups, and this requires more attention in $\mathrm{TB}$ control programs aiming at these age groups. The highest percentage of PTB (66.2\%) was registered in 2014, and the highest percentage of EPTB ((51.6\%) was registered in 2017. In our study, the most common type of patients were new cases, smearpositive, and increased percentage of cure outcome during the period from 2014 to 2018 in Giza Governorate.

Limitation of the study The unavailability of clinical data, radiologic findings, and other laboratory investigations, in particular, the culture results of patients, are the limitations of this study.

\section{Abbreviations}

TB: Tuberculosis; PTB: Pulmonary tuberculosis; EPTB: Extrapulmonary tuberculosis; NTB: The National Tuberculosis Control Program; WHO: World Health Organization; HIV: Human immunodeficiency virus

\section{Acknowledgements}

Not applicable

\section{Authors' contributions}

ARA conceived of the presented idea, recorded the data, and wrote the manuscript with the support of HHE. AEA developed the theory and performed the computations and verified the analytical methods. The authors have read and approved the final manuscript and ensure that this is the case.

\section{Funding}

Nil

\section{Availability of data and materials}

All data generated or analyzed during this study are included in this published article (and its supplementary information files).

\section{Declarations}

\section{Ethics approval and consent to participate}

Ethics approval to use, report, and publish the collected data was obtained from the Ministry of Health, Egypt. Patient information was anonymized and de-identified prior to the analysis. Also, this study was approved by the Institutional Review Board of the Faculty of Medicine for Girls (the committee's reference number IRB 201910179), Al-Azhar University/Cairo branch on October 1, 2019, and was obliged to the standards of the Declaration of Helsinki.

Consent for publication

Not applicable

\section{Competing interests}

The authors declare that they have no competing interests.

\section{Author details}

${ }^{1}$ Chest Disease Department, El Aiat Chest Hospital, Giza Govrnorate, Cairo, Egypt. ${ }^{2}$ Chest Department, Faculty of Medicine for Girls, Al-Zahraa University Hospital, 11517 Al-Abbaseya, Cairo, Egypt.

Received: 16 February 2021 Accepted: 11 April 2021

Published online: 29 April 2021

\section{References}

1. Mohamed A, Mohamed G, Ahmed F (2010) A study of tuberculous cases admitted at Assiute Chest Hospital during period (2005-2009). South Vally University

2. Tadesse T, Demissie M, Berhane $Y$, Kebede $Y$, Abebe M (2011) Two-thirds of smear-positive tuberculosis cases in the community were undiagnosed in Northwest Ethiopia: population based cross-sectional study. PLoS One. 6(12): e28258. https://doi.org/10.1371/journal.pone.0028258

3. Sobh E, Kinawy SAE, Abdelkarim YMA, Arafa MA (2016) The pattern of tuberculosis in Aswan Chest Hospital. Egypt. Int J Mycobacteriol. 5(3):333340. https://doi.org/10.1016/j.ijmyco.2016.08.001

4. Caylà JA, Orcau A (2011) Control of tuberculosis in large cities in developed countries: an organizational problem. BMC Med. 9(1):127. https://doi.org/1 0.1186/1741-7015-9-127

5. Zumla A, Chakaya J, Centis R, D'Ambrosio L, Mwaba P, Bates M et al (2015) Tuberculosis treatment and management-an update on treatment regimens, trials, new drugs, and adjunct therapies. Lancet Respir Med 3(3):220-234

6. Alwani AK, Al-Aarag AH, Omar MM, Hibah NA (2015) Incidence of tuberculosis before and after DOTS (direct observed therapy short course strategy) implementation in El-Behira Governorate, Egypt. Egypt J Bronchol 9(1):101-108

7. Khalifa HK, Al-Aarag AH, Omar M (2014) Tuberculosis situation in Gharbia Governorate (1994-2010) before and after direct observed therapy short course strategy DOTS. Benha Fac Med

8. Zedan M, Al Wakeel E, Shaarawy AT, Nour M (2015) Pattern of tuberculosis in patients of a university hospital during the period (2004-2011). Egypt J Chest Dis Tuberc. 64(1):85-89. https://doi.org/10.1016/j.ejcdt.2014.09.003

9. Shabana SMA, Omar MM (2015) Al mehy GF, Mohammad OE, Eldesouky RS. Tuberculosis situation in port said governorate (1995-2011) before and after direct observed therapy short course strategy (DOTS). Egypt J Chest Dis Tuberc. 64(2):441-447. https://doi.org/10.1016/j.ejcdt.2014.12.008

10. Eastwood SV, Hill PC (2004) A gender-focused qualitative study of barriers to accessing tuberculosis treatment in The Gambia, West Africa. Int J Tuberc Lung Dis. 8(1):70-75

11. Ambrose JA, Barua RS (2004) The pathophysiology of cigarette smoking and cardiovascular disease: an update. J Am Coll Cardiol. 43(10):1731-1737. https://doi.org/10.1016/j.jacc.2003.12.047

12. Mori T, Leung CC (2010) Tuberculosis in the global aging population. Infect Dis Clin North Am. 24(3):751-768. https://doi.org/10.1016/j.idc.2010.04.011

13. Negm MF, Al mehy GF, Ali TM, Abd Elfadil SS (2016) Tuberculosis situation in Ismailia governorate (2002-2012) before and after Direct Observed Therapy Short Course Strategy (DOTS). Egypt J Chest Dis Tuberc. 65(1):211217. https://doi.org/10.1016/j.ejcdt.2015.09.005

14. Negm MF, Allam AH, ElZeheiry AH (2017) Assessment of directly observed therapy short-course (DOTs) of tuberculosis in Dakahlia governorate chest hospitals from 2006 to 2011. Egypt J Bronchol. 11(2):88-97. https://doi.org/10.4103/ejb.ejb_55_16

15. Mohammadien H, Alkhayat K, Hamed A, Shaaban M (2017) Patterns, trends and treatment outcomes of extra-pulmonary tuberculosis in Sohag, Upper Egypt. Egypt J Chest Dis Tuberc. 66(2):313-316. https://doi.org/10.1016/j.ejcdt.2017.02.001

16. Nafae RM, Elshahat HM, Said AM, Ibrahim MA (2017) Reviewing treatment outcomes of tuberculosis patients at Zagazig Chest Hospital (2008-2012). Egypt J Chest Dis Tuberc. 66(4):623-630. https://doi.org/10.1016/j.ejcdt.2017.10.006

17. Essawy T, Eissa S, Okab A, El Ghany E (2016) Assessment of tuberculosis situation in Cairo governorate from 2006 to 2012 after application of directly observed therapy short-course strategy. Egypt J Bronchol. 10(1):52

18. Allam A, Negm M, Goda T, Elawady M (2019) Tuberculosis in Upper and Lower Egypt before and after directly observed treatment short-course strategy: a multi-governorate study. Egypt J Bronchol. 13(5):722

\section{Publisher's Note}

Springer Nature remains neutral with regard to jurisdictional claims in published maps and institutional affiliations. 